DEPÓSITO LEGAL ZU2020000153

Esta publicación científica en formato digital

es continuidad de la revista impresa

ISSN 0041-8811

E-ISSN 2665-0428

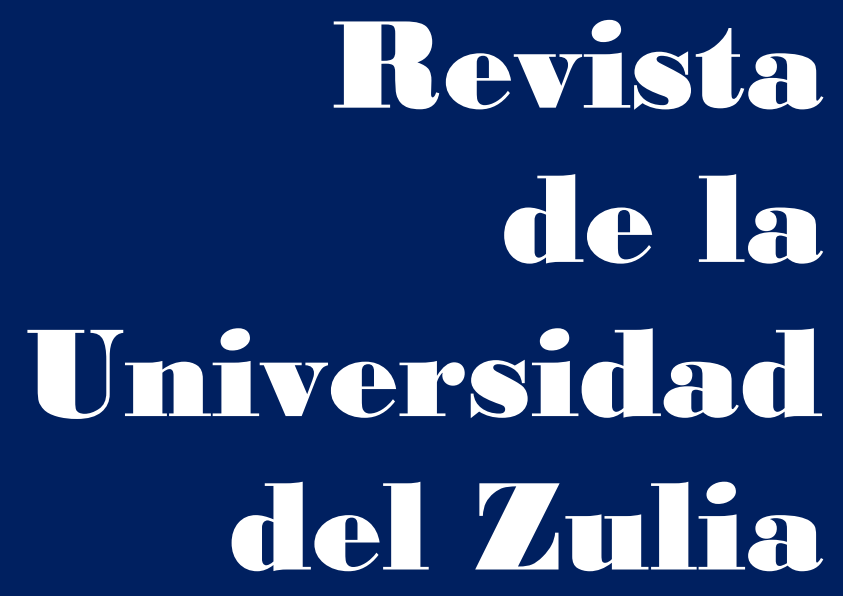

Fundada en 1947

por el Dr. Jesús Emrique Lossada

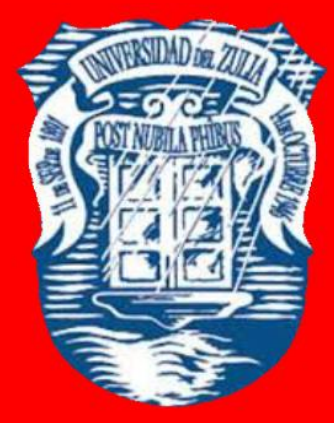

Ciencias

Sociales

y Arte

Año $12 \quad N^{\circ} 34$

Septiembre - Diciembre 2021

Tercera Época

Maracaibo-Veneruela 


\title{
The role of civil society institutions in ensuring social control over political processes
}

\author{
Serhii O. Komnatnyi * \\ Hanna S. Buha ** \\ Anna M. Fedorova *** \\ Valerii M. Horovyi $* * * *$ \\ Kateryna V. Bortniak *****
}

\begin{abstract}
The purpose of the article is to investigate the importance and roles of civil society institutions in exercising social control over policy formulation and implementation processes, even in conditions of pandemic contingency. The study has used the methods of comparative analysis, temporal analysis, case study method, statistical data analysis and secondary research of the results of sociological studies. It has been established that civil society institutions play the role of efficient institutions of social control. They are able to mutually strengthen the intentions of the State to ensure the public interest, establish the collaboration of citizens and the cohesion of public efforts. In Ukraine, so far, civil society is at a stage of development and, along with the quantitative characteristics, does not have the appropriate qualitative characteristics. Social control is not authoritarian in nature, nor is it mandatory; it is carried out on behalf of its actors: civil society and citizens.
\end{abstract}

KEYWORDS: Social control; Social participation; civil society; democracy; politics.

*Department of Civil Law Disciplines, National Academy of Internal Affairs, Kyiv, Ukraine. ORCID: https://orcid.org/0000-0002-2124-2047. E-mail: sergii02021983@gmail.com

**Department of Administrative and Law Disciplines, Faculty \$2, Donetsk law institute of MIA of Ukraine, Mariupol, Ukraine. ORCID: https://orcid.org/0000-0003-3957-7387. E-mail: kuzianna@ukr.net

***Department of Public Administration and Innovation Management, Education and Research Institute of Continuing Education, National University of Life and Environmental Sciences of Ukraine, Kyiv, Ukraine. ORCID: https://orcid.org/0000-0001-8833-6606. E-mail: 99849@i.ua

****National Library of Ukraine named after V. I. Vernadsky, Kyiv, Ukraine. ORCID: 0000https://orcid.org/0002-2644-5249. E-mail: valeriihl77@gmail.com

*****Department of Public and Private Law, Kyiv V. I.Vernadsky Taurida National University, Kyiv, Ukraine. ORCID: https://orcid.org/0000-0002-2135-3820. E-mail: Tnu2019@meta.ua 


\section{El papel de las instituciones de la sociedad civil para garantizar el control social de los procesos políticos}

RESUMEN

El propósito del artículo consiste en investigar la importancia y las funciones de las instituciones de la sociedad civil en el ejercicio del control social sobre los procesos de formulación e implementación de políticas, incluso en condiciones de contingencia pandémica. El estudio ha utilizado los métodos de análisis comparativo, análisis temporal, método de estudio de casos, análisis de datos estadísticos e investigación secundaria de los resultados de estudios sociológicos. Se ha establecido que las instituciones de la sociedad civil desempeñan el papel de instituciones eficientes de control social. Son capaces de fortalecer mutuamente las intenciones del Estado para velar por el interés público, establecer la colaboración de la ciudadanía y la cohesión de los esfuerzos públicos. En Ucrania, hasta ahora, la sociedad civil se encuentra en una etapa de desarrollo y, junto con las características cuantitativas, no tiene las características cualitativas adecuadas. El control social no es de naturaleza autoritaria, ni es obligatorio; se lleva a cabo en nombre de sus actores: la sociedad civil y los ciudadanos.

PALABRAS CLAVE: Control social; participación social; sociedad civil; democracia; política.

\section{Introduction}

The issue of social control over political processes is particularly urgent in the context of downturn of the level of trust in State institutions, the growth of populist sentiments and the need to increase the quality of policy. The public discourse discusses the effectiveness of various mechanisms of such control, the possibility of involving more citizens of different ages in public consultations and constructive participation in the processes of development and implementation of public policy.

Therefore, the purpose of this work is to investigate the importance and functions of civil society institutions in ensuring social control over the processes of development and implementation of public policies. In order to achieve that goal, it is necessary to solve the following research tasks: 1) analysis of the purpose and peculiarities of social control in modern conditions to ensure the quality of public policy; 2) identification of problems of active participation of civil society institutions in the processes of social control and development of recommendations for their solution in Ukraine. 


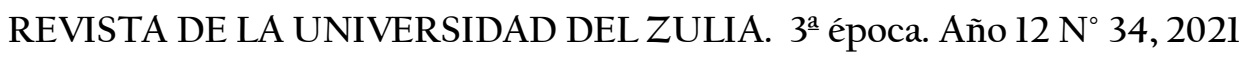

Serhii O. Komnatnyi et al// The role of civil society institutions in ensuring social control... 341-360 DOI: $\underline{\text { http://dx.doi.org/10.46925//rdluz.34.20 }}$

\section{Literary review}

Global democratization processes, the growing importance of self-organization of the population and participation of the general public in public policy-making are also strengthened by decentralization processes in public administration, which have become vectors in the countries currently undergoing secondary modernization. A lot of modern researchers in their works consider various aspects of ensuring social control by means of public organisations (Marañón et al, 2021).

Leigh (2019) views this issue through the prism of the development of public spaces and modern urban planning. After all, materialized spaces and the availability of other resources to ensure them should be, among other things, an important condition for ensuring social control. The researcher analyses how social control affects the quality of public policy in the development of social infrastructure (Leigh, 2019). McHale (2019) focuses his research on the role of media in supporting social control, policy-making and policy implementation in modern democracies. The retrospective method, used in the researcher's works, is quite valuable, as it is used as an analytical lens, through which it is possible to determine the importance of media as a powerful means of social control. Media, as a civil society institution, have always played a constructive role in the development of public policy and its implementation. At the same time, McHale (2019) analyses the destructive effects from the influence of media, in particular the fact that social media contribute to the division of public discourse into opposing parties. The researcher analyses the cases of dissemination of discursive and, consequently, social chaos through disinformation campaigns, bringing us to the idea that the media is both a separating and a unifying force. However, the growth of social media and their susceptibility to manipulation constitutes a danger to social cohesion, effective public policy-making and implementation of State policy, which affects the lack of clarity in policy objectives and the quality of the political process.

Another theorist Swain (2019) analyses the functions of public sports organizations in ensuring social control. Socio-historical analysis, performed by the author, is useful for understanding the role of sports initiatives in the public sector for the development of national social policy. It is possible to trace in the works of Swain (2019) how the methods of exercising public authority have changed from industrial times to post-industrial conditions. Currently, the definition of sports as a part of public culture in terms of the covid- 
19 pandemic helps in the implementation of policies to promote healthy lifestyle, motivation to physical activity and anti-ageism.

The researchers Klein and Lee (2019) look into the processes of interrelation and collaboration between the civil society, the State, and the economy, where each agent shapes different engagement strategies. These strategies include, in particular, the policy of influence, the policy of substitution and the policy of occupation, which conform to the strategies of discursive impact, functional substitution and takeover of institutions, respectively. The scholars emphasize that either civil society can interfere in the actions of the State and the economy can react in response to the actions of the State, or the State and the economy can as well interfere with the activities of civil society.

Antje and Dieter (2019) have researched the application of well-established notions of civil society in new democracies. The scientists highlight the special cases of third world countries and low efficiency of secondary modernization in African countries. With regard to the analysis of social control, the scientists have found out interesting consequences of the improvement of the quality of policy as a result of active efforts of civil society institutions (Antje \& Dieter, 2019). In this discussion, Cooper (2018) stresses that civil society groups are becoming more technologically literate using social media platforms. Jezard (2018), in turn, adds to such platforms new technological tools, used by civil society institutions in order to increase the efficiency of their work. For example, the World Wildlife Fund uses drone technologies, animal tracking devices and infrared cameras to combat poaching of endangered species (Jezard, 2018). The UNICEF U-Report bot is a free tool for social monitoring. Thanks to the bot, according to Jezard (2018), it became possible to uncover a scandal over exploitation of children by their teachers in Liberia. In less than a day, 13,000 people were involved in the public debate and, as soon as the problem went public, a support service was established and advisory services were appointed (Jezard, 2018).

Social control as an anti-corruption practice was analysed by Langseth (2001). In cases where institutions, designed to ensure respect for human rights, are treated by the citizens as the most corrupted ones, the social consequences of such a process have destructive impact on socio-political processes. Systemic corruption undermines the legitimacy of the State and the democracy itself. Langseth (2001) justifies the importance of systematic, reliable and transparent monitoring of the levels, types, localization, causes of corruption and 
anti-corruption strategies. According to the researcher, this is possible by improving access to reliable mechanisms of social control by civil society institutions, which will significantly strengthen the anti-corruption approach, aimed at the collection of empirical data.

The scholar Lorch (2017a; 2017b) emphasizes in her works that the concept of civil society should be systematically contextualized. The theorist Howell (2019) analyses temporal cases of complex policies, developed through the pluralisation of public discourse in transition countries, the development of a mechanism of social control through the involvement of civil society institutions.

Particularly noteworthy among the latest works is the work of Brechenmacher et al. (2020), which identifies the challenges of the activities of civil society organizations in times of economic crisis. Despite the sufficient coverage of the topic of social control of civil society institutions in various aspects by modern theorists, the scholars have not yet developed common position on the clear distinction between the definitions of "civil control" and "social control". It is necessary to give integrated assessment of the opportunities and development of capabilities for social control in modern conditions. In view of the aforesaid, we will try to reveal the indicated inconsistencies in this work.

\section{Methods}

The research procedure comprised the preparatory phase and the field survey phase. The preparatory phase included content analysis of scientific literature on the topic, analysis of analytical reports of international organizations, international projects, content of sites and information portals of the public authorities and civil society institutions. The field survey phase involved carrying out qualitative sociological studies.

The article uses qualitative methodology with the combination of two methods: indepth interviews and focused in-depth interviews. Combination of the two methods of qualitative research allowed to obtain the widest range of opinions and to create group dynamics in order to update and problematize the issues, related to social control in Ukraine, by different target groups.

Transcripts of 15 in-depth interviews and 5 focus groups were obtained based on the results of the field survey phase. 
The in-depth interview method involves individual meetings with the representatives of certain target groups in order to study their views on social control in Ukraine and their attitude to it. Such an interview is conducted using open-ended questions and may not be clearly structured. It allows you to identify the subconscious attitude of the target audience to the problematic issues, namely: thoughts, motives, feelings, ideas, views of the respondents.

The procedure for the organization and conduct of an in-depth interview included the following stages: drawing up an in-depth interview plan for each of the identified target groups; the process of planning and preparing for an interview; organizing and conducting an interview; processing and analysis of the obtained results; report preparation.

In-depth interviews were aimed at identifying the peculiarities of perception of functions and means by various groups of the public concerned (the representatives of civic organizations, local government officials, local youth, local executive authorities, local media, active citizens, social workers (teachers, doctors).

The planning and preparation phase for the interview involved establishing contacts with active public organisations in the regions of Ukraine. After that, the "snow-ball method" was used to search for respondents. The main criteria, which were used for selecting respondents for in-depth interviews, included: 1) belonging to one of the target groups; 2) accessibility and motivation to participate (based on the results of a preliminary interview), the ability to provide qualitative, detailed and reliable information on the process of social control; 3) adherence to gender balance in the selection of participants (Brick, 2018).

In the implementation phase, there were used various questions from the guide-book, including open-ended questions, game elements and techniques which helped to reduce emotional tension and to establish friendly and partnership relations with the respondents, the techniques that stimulated the story-telling or, vice-versa, helped to "cut off" spin-off topics, irrelevant to the study.

Three people were trained and participated in interviewers. A total of 15 in-depth interviews were conducted with the representatives of 7 target groups.

The peculiarities of organizing and conducting focus group interviews as a method of obtaining quality information are as follows. 
A focus group interview is a square talk of a group of strangers or a group of people who hardly know each other, in a comfortable setting. The method allows to obtain the most complete picture of public opinion from a certain audience, revealing the obvious and hidden motives of behavior, factors shaping judgments and attitudes.

Key selection criteria for each focus group are as follows:

1. Preliminary interview with each participant in order to determine the socioeconomic characteristics so as to balance gender, age and status;

2. The participants of adult groups should not be the representatives of one working group;

3. Students and schoolchildren (students of vocational (professional and technical) education institutions, college students, school students) may be the representatives of one school, but there should be no more than 3 people from the same class.

Recruitment of participants is targeted selection of respondents in different regions of Ukraine regarding their geographical location and other defined criteria. A total of 5 focus group interviews were conducted with the representatives of civic organizations, local government officials, local media, active citizens, social workers (teachers, doctors).

It is important to emphasize that all working meetings, without any exceptions, took place online in view of the pandemic.

The study has also used the method of secondary research of the results of sociological studies. Sociological polls, which can be defined as mass sociological surveys, were conducted by the sampling method. The sampling, built on the principle of stratification, was representative of the whole of Ukraine, as the stratum were the respondents from all regions of Ukraine. The confidence figure (accuracy) in the study was $95 \%$, the measure of inaccuracy can count to $2-3 \%$.

The methodology for the analysis of social control, used in the study, is aimed at reflecting different positions of all the participants and all the parties concerned. The relativistic approach, that connects civil society with the context of its actions and activities, has proved to be a fruitful approach to the analysis of social control.

The method of secondary research of the results of sociological studies was used to justify the degree of legitimacy of social control over civil society institutions. The study analysed mass sociological surveys with the representative sample by gender, age, and 
territorial characteristics. The total respondent population in such studies was over 2,000 people, with the measure of inaccuracy no more than $2.5 \%$. The study also used such type of comparative methods as the binary method in the analysis of a number of quantitative characteristics of civil society in different countries.

\section{Results}

According to the results of focus group surveys, $80 \%$ of representatives of public organisations are almost or fully prepared to exercise social control over the activities of public authorities. But the problem is that $50 \%$ of them lack certain resources: time, finances and most importantly - professional human resources with the developed constructive competence to negotiate with the State.

Only $60 \%$ of the representatives of local authorities are ready to accept public organisations as fully-fledged partners in the process of exercising their functions of social control.

According to the results of the interviews, only $20 \%$ of the representatives of local executive authorities are ready to accept public organisations as fully-fledged partners performing social control over the activities of public authorities. Moreover, according to public officials, public organisations are not ready to hold the sufficiently professional discussion on public sector reform.

The interviewed youth representatives showed more passive than active position on the issue of systematic participation in social control over the activities of local authorities, but more active than passive position regarding the issue of social control over the activities of central government bodies.

The representatives of the social sphere were ready to participate in the implementation of social control over the activities of public authorities by $40 \%$ only, justifying it by potentially low effectiveness of such participation.

In general, the case of modern Ukraine, in the context of various social and professional groups, gives grounds for asserting positive dynamic in the development of civil society over the years of independence (see Figure 1 and Figure 2).

But the number of registered public organizations in Ukraine does not automatically imply high level of quality of social control over their political processes (see Table l). 


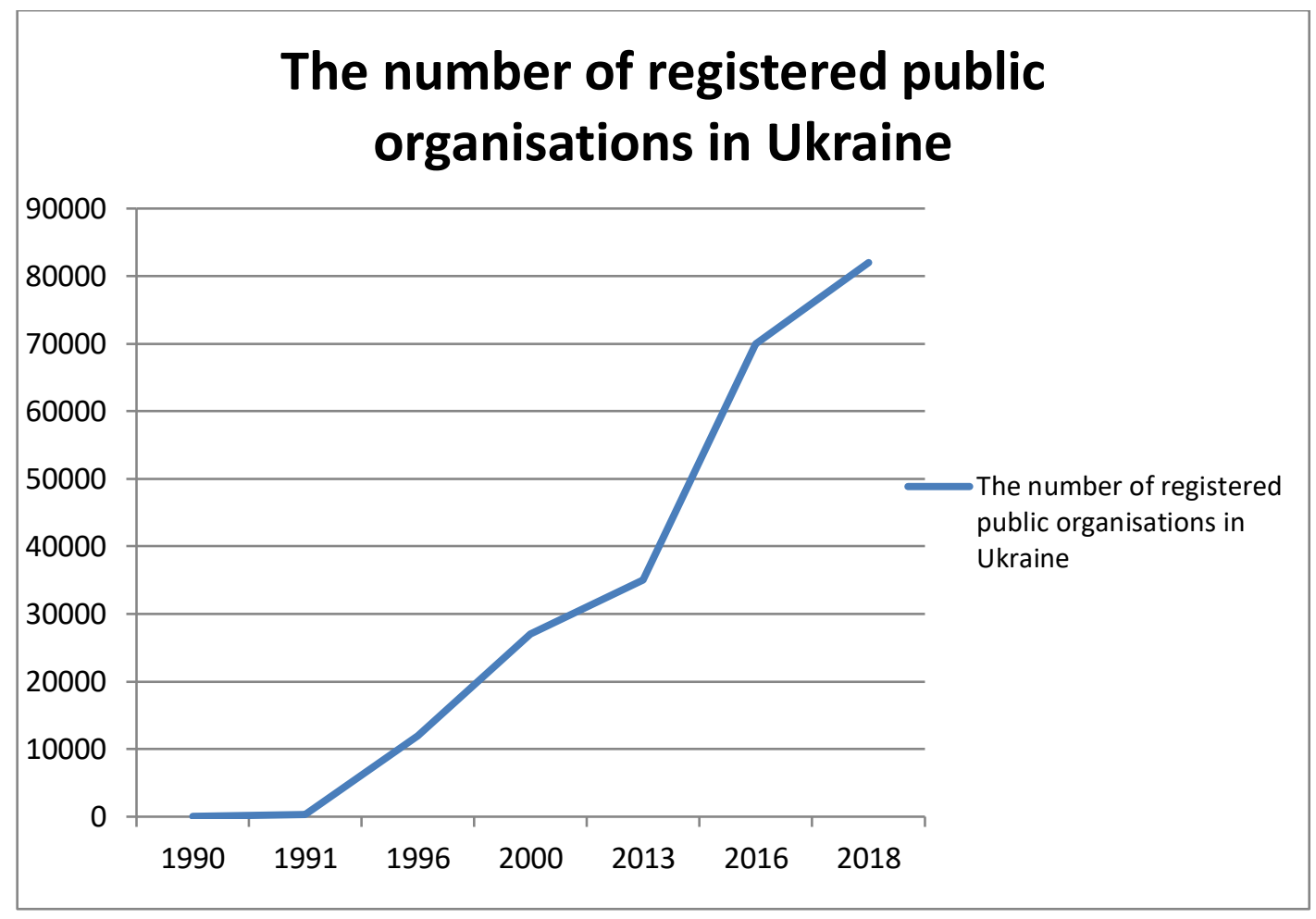

Figure l. The growth dynamics of the number of public organisations in Ukraine (based on the materials of the State Statistics Committee of Ukraine (n./d.))

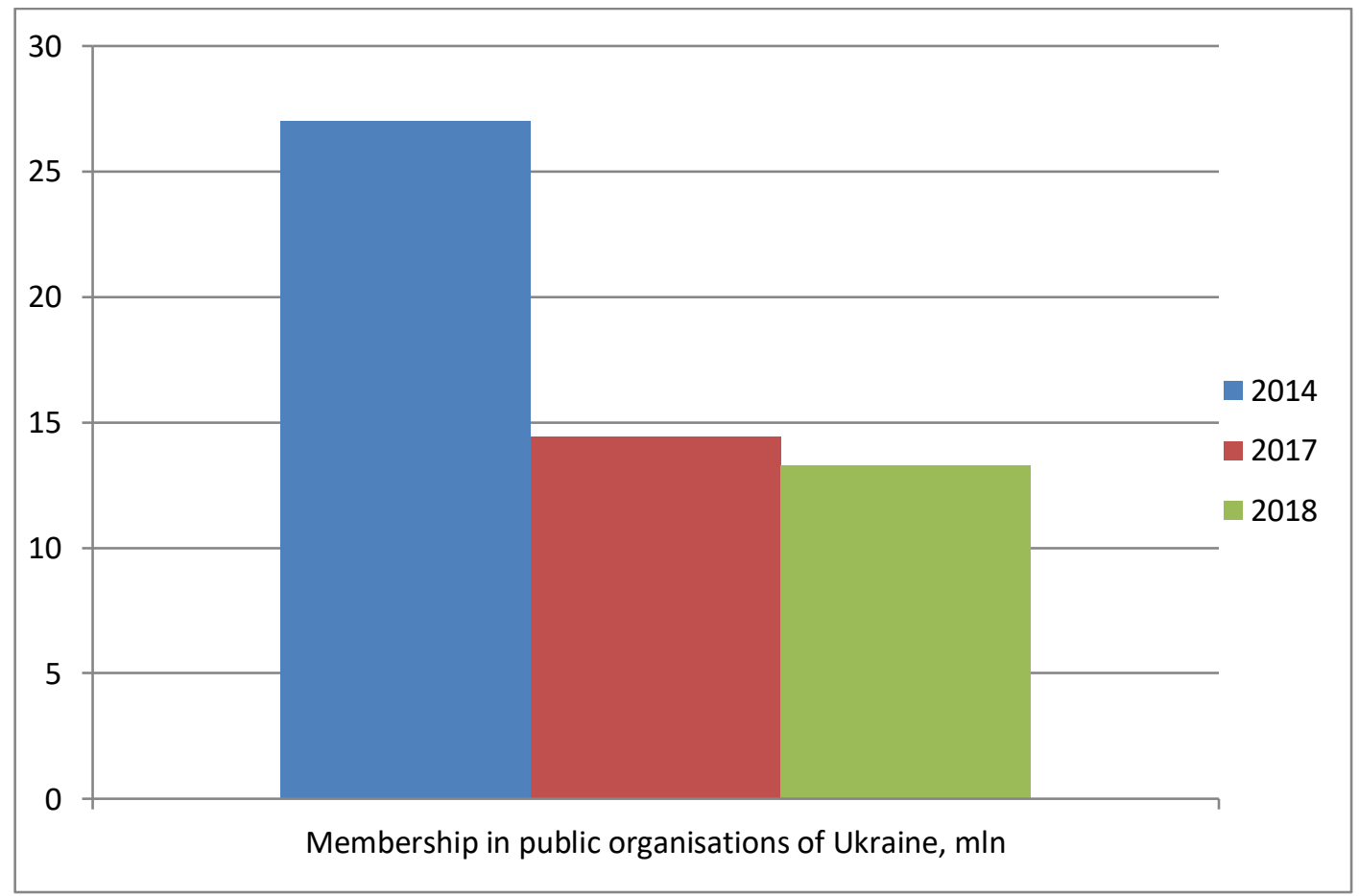

Figure 2. Dynamics of membership in public organisations in Ukraine (based on the materials of the State Statistics Committee of Ukraine (n./d.)) 
Table l. The level of citizens' confidence in civil society institutions and other public organisations of Ukraine

\begin{tabular}{l|c|c}
\hline Institutions & $\begin{array}{c}\text { Citizens' confidence, \% of } \\
\text { people polled, 2015 }\end{array}$ & $\begin{array}{c}\text { Citizens' confidence, \% } \\
\text { of people polled, 2020 }\end{array}$ \\
\hline Church & 58,8 & 63 \\
\hline Volunteers & 57,6 & 63 \\
\hline Armed Forces of Ukraine & 45,3 & $\underline{47}$ \\
\hline Non-governmental & $\underline{34,5}$ & 50 \\
organisations & 32,3 & 44,4 \\
\hline Ukrainian mass media & 16,8 & 33 \\
\hline The President of Ukraine & 14,9 & 21,1 \\
\hline $\begin{array}{l}\text { National Police } \\
\text { The Government of }\end{array}$ & 8,7 & 18,6 \\
\hline Ukraine & 6,2 & \\
\hline $\begin{array}{l}\text { The Verkhovna Rada of } \\
\text { Ukraine }\end{array}$ & & \\
\hline
\end{tabular}

Source: The author's development based on empirical evidence Razumkov centre (n./d.)

As you can see, the level of confidence in public organizations in Ukraine has grown. But this is unlikely to be the result of increase in the quality of social control by public organisations, as stabilizing force in the social development in Ukraine in 2020, compared to the open armed phase of the conflict and armed aggression in Ukraine in 2015. Moreover, the predominance of the level of confidence in volunteers over the level of confidence in public organisations indicates some problems in the functioning of public organisations (the socalled "dark sides"), which may relate to unwillingness to collaborate with other public organisations, difficulties in bureaucratic procedures regarding formalisation of their activities and etc.

A democratic social welfare state shall provide for reciprocal responsibility of the State, society, business and citizens. However, day-to-day realities of this responsibility in 
the case of the transit country of Ukraine are different. The case of Ukraine illustrates the realities of "a person is for the State" situation rather than "the State is for a person" one. Table 2 shows that the authorities in Ukraine have low level of legitimacy. For example, the level of confidence in the only legislative body in Ukraine - the Parliament - is only $18.6 \%$, which is even below the classic "threshold of legitimacy" $-20 \%$, after which the crisis of legitimacy occurs.

Table 2. The results of sociological polls, conducted in order to determine the organisations that Ukrainian citizens trust the most in protecting their rights.

\begin{tabular}{|c|c|c|}
\hline \multirow{5}{*}{$\begin{array}{l}\text { Where would you } \\
\text { turn in cases of } \\
\text { violation of your } \\
\text { rights (survey of the } \\
\text { citizens of Ukraine, } \\
\text { 2017) }\end{array}$} & Answer options & $\begin{array}{l}\text { Affirmative answers of } \\
\text { the citizens, in \% }\end{array}$ \\
\hline & to mass media & 28 \\
\hline & $\begin{array}{l}\text { to European Court of Human } \\
\text { Rights }\end{array}$ & 19 \\
\hline & to the police & 10 \\
\hline & to the court & 16 \\
\hline & to local authorities & 8 \\
\hline
\end{tabular}

Source: Human Rights (2017)

54\% of Ukrainians have never tried to protect their rights (Human Rights, 2017). The crisis of confidence in the authorities is evidenced by the fact that in 2017 the Ukrainians did not call the judiciary or public order bodies the leaders in the effectiveness of human rights protection in Ukraine.

Appreciation of media in defending the rights of citizens shows high potential that media demonstrate as a civil society institution in performing the functions of social control. However, $65 \%$ of those, who tried to protect their rights in Ukraine, failed, which proves that there are no effective ways to protect human rights in Ukraine. Besides, there is a significant demand for increasing the quality of social control over the actions of the authorities and improving the human rights situation in Ukraine. 
Let's compare the state of development of civil society in Ukraine and in Poland, which is close to Ukraine in terms of population (see Table 3). For comparison, we have chosen 2013, which was more or less similar in the dynamics of socio-political processes in the two countries, namely we have considered the period before the start of civil protests in Ukraine called the "Revolution of Dignity" (which began in late November 2013).

Table 3. Quantitative characteristics of civil society in Ukraine and Poland as of the second half of 2013 (the author's development)

\begin{tabular}{|c|c|c|}
\hline & Ukraine & Poland \\
\hline $\begin{array}{l}\text { The number of public } \\
\text { organisations } \\
\text { (approximately) }\end{array}$ & 35000 & 35000 \\
\hline $\begin{array}{l}\text { Members of public } \\
\text { organisations }\end{array}$ & $8.1 \%$ of the population & $20 \%$ of the population \\
\hline $\begin{array}{l}\text { Contributions from foreign } \\
\text { grant sponsors in the } \\
\text { system of financing the } \\
\text { activities; }\end{array}$ & $50 \%$ & $20 \%$ \\
\hline $\begin{array}{l}\text { Funding from self- } \\
\text { government organisations }\end{array}$ & $\begin{array}{l}\text { There is little funding, } \\
\text { associated with } \\
\text { corruption risks }\end{array}$ & $\begin{array}{l}\text { 50-60\% of organisations received } \\
\text { budget support from local } \\
\text { governments. Since 2004, 1\% of } \\
\text { the tax paidby the citizens during } \\
\text { the preparation of the annual tax } \\
\text { report can be transferred to } \\
\text { public organisations. }\end{array}$ \\
\hline $\begin{array}{l}\text { Social, cultural, economic } \\
\text { interests of the citizens in } \\
\text { relations with the State are } \\
\text { represented by }\end{array}$ & $\begin{array}{l}\text { No more than } 20 \% \text { of } \\
\text { public organisations }\end{array}$ & $\begin{array}{l}\text { More than } 75 \% \text { of public } \\
\text { organisations }\end{array}$ \\
\hline $\begin{array}{l}\text { The number of registered } \\
\text { parties }\end{array}$ & 201 & 75 \\
\hline
\end{tabular}

Based on the figures of membership in public organisations in Ukraine and Poland, it becomes clear that the public sector in Ukraine is more fragmented. At the same time, in 
Poland almost all public organisations are large, credible, and effective in exercising social control. Therefore, it is not surprising that more than $80-85 \%$ of the Poles trust them.

In Ukraine, for example, in the research year (2013):

- only $35.1 \%$ of public organisations submitted reports;

- only $8 \%$ of public organisations have national and international status;

- about $20 \%$ of public organisations are not located at the legal address;

- violations of the Statute and of the legislation of Ukraine have been found in the activities of $20 \%$ of public organisations;

- "less practical measures", such as holding various conferences and round-table discussions, predominate (more than 50\%) in the activities of public organisations.

All this indicates the weakness of the institutional capacity of public organisations in Ukraine to exercise social control of appropriate quality over political processes. One of the reasons for low institutional capacity is scattered efforts of public organisations and fragmentation of civil society, small number of powerful and authoritative public organisations, reluctance of smaller public organisations to unite in order to synergistically strengthen each other's social control over political processes (Ivchenko, 2017).

Another important task for exercising social control in terms of the pandemics is consolidation of efforts and assistance to community groups in order to unite effectively for an equitable dialog with the authorities. Civil society institutions, in search of additional sources of funding, could act as implementing partners in the areas, where there is limited presence of the State or low public confidence in the authorities.

\section{Discussion}

The study has defined, based on empirical evidence, insufficient level of involvement of civil society institutions in Ukraine in implementation of social control, despite certain institutional, ideological and staff capacities. It can be said that the public sector of Ukraine remains quite fragmented and unconsolidated. Despite the large number of public organizations, the dynamics of membership in these organizations is low. This interferes with the increasing role of public participation in the conduct of public affairs. It should be emphasized that public participation is not of systematic and constructive nature, but it is crisis-related and remonstrative (Ryabov, 2004). 
The support of social partnership in Europe is currently an ongoing process of timely administrative reforms and modernization of political process. There are three sets of policies that influence this policy process: inter-institutional policy; public sector policy/nongovernmental sector policy and internal policy/external policy. Moreover, especially important and crucial are the processes of gradual institutional changes, adopted by the key political actors in order to achieve the goals of building consolidated democracy. Therefore, the strengthening of state unity contributed meaningfully to the development of immature civil society, and vice versa (Green, 2017; Greer, 2017).

Researchers Brechenmacher et al. (2020) emphasize that new forms of civic mobilization and solidarity are likely to suffer significantly from the pandemic economic crisis. Civil society organisations (especially recently established ones) may lose important sources of funding - funds, while independent media organisations will experience a steep decline in advertising revenues. This tendency may accelerate the growth of informal activities in the public sector in comparison with formal activism. As a result, smaller public organisations will collaborate and unite. At the same time, public and private actors, willing to support civil society, hurry to adapt to the new global context. They need to become more flexible in providing assistance to civil society actors, linking them to larger support packages. This is important in a pandemic, as well as strengthening of political positions on the value of civil society in general. Modern researchers advise civil society institutions, in volatile environments of public sector development, to try to form unexpected coalitions and to experiment with new initiatives, to continue to support local public organisations until the recovery stage (Brechenmacher et al., 2020).

In a pandemic, the important role of social control of civil society institutions is to monitor new support packages and new support for the journalists and anti-corruption organisations, which protect the proper quality of public service in the context of procurements and implementation of management processes in the time of COVID-19. It is important that the emergency situation and unpredictability of social processes during the COVID-19 period would not lead to the strengthening of State control, to which frightened and disoriented public can tend. Democratic participation and social control are even more important in terms of the pandemics, as public space must be fully operational and develop in any case. Bureaucratic differences in the activities of certain organisations should not 
prevent bringing together in order to respond to threats. And in many countries, one can find examples of local community groups succeeding in something governments fail to do, using their resources for the common good (Brechenmacher et al., 2020). The pandemic period, naturally, suggests support in the fight against the coronavirus, but at such times the public sector should support confronting the policy of excessiveness and punitive restrictions on civil liberties. It is also time to strengthen rather than reduce international commitments to build public space and inculcate democratic values in general.

Non-parliamentary parties are of civil society institutions as well. Due to its strong organizational orientation to participate in political life, a party is an effective expression of the needs and goals of certain social groups, moreover, it contributes its driving force to the governance and determines the direction of activities of public authorities. In a democracy, political parties do not just represent the interests of different groups, they will formalize and justify them ideologically - in the form of systematized program requirements for the authorities and the State policy. Parties go beyond mere representation of various social interests, but organize and represent them in the political process as well, participating in the development and conduct of public policy. As electoral tools, the parties contribute to the involvement of citizens in politics, namely in the organization and structuring of the political process in democratic systems. By interaction with each other and with public and local authorities, political parties can reconcile different, usually competing social interests, thus removing social and class differences and overcoming social tensions without aggression and violence, through compromise (Galston, 2004).

Since most modern parties strive to be parties for everyone, not just for one social group, they offer society the values that can unite the majority of citizens. The party, performing its electoral function, inevitably influences public opinion, trying to convince the voters of the optimality of its own party platform (VanDyck, 2017).

Thus, parties are organized political forces that unite the citizens with common political views with the purpose of mobilization of public opinion concerning a certain number of goals and in order to fight for meeting these requirements at the level of the authorities. The quality of democracy depends on whether the parties have managed to become the real centres of accumulation of society's potential, whether they have different semantic identity, or whether they have a sense of political responsibility (Semenets-Orlova 
$\&$ Kyselova, 2018; Primoratz, 2017). Multi-party system, based on the appropriate legislative frameworks, is one of the factors and guarantors of respect for human rights and freedoms, the progress of a stable political system, reforming economic and social relations, raising the welfare, spirituality and culture of the Ukrainian people. Characteristic features of Ukrainian political parties are: the team work of most parties; lack of the developed social base and even of ideas about it; the informal formation of electoral blocs; sudden change of attitude of parties towards certain political leaders; clear association of parties and their leaders with financial and economic structures; the failure of attempts to form a powerful bloc of centrist political parties. Orientation of a significant part of the parties towards the middle class does not take into account the current structures of society and is designed for the future (Taleb, 2018). Some parties have declared themselves to represent the interests of the classes that are yet to be formed, and such an orientation is forward-looking.

Civic education (Starkey, 2002) and high level of developed culture of citizenship are of great importance for ensuring the activity of citizens in the development of public policy and implementation of social control. According to the Council of Europe, democratic citizenship includes social cohesion, justice, solidarity, participation in democratic life and culture and values, that relate to the exercise of the person's rights and responsibilities in society. In terms of education, knowledge of democratic practices, skills and commitment to values, that will enable the citizens to effectively influence policy at the local, regional and national levels, are important for democratic citizenship (Cambridge Dictionary, 2021).

\section{Conclusion}

The institution of social control plays an important role in the development of a new quality of public policy and the development of consolidated democracy. Social control aims to regulate the relationship between the individual and society in order to strengthen the rule of law and stability, as well as to prevent and correct deviant behavior (Etzioni, 1968). A modern State seeks to change the nature of governance. To this end, the State transfers the functions of control of public institutions to informal institutions, which contributes to the development of civil society and increase of its self-governing capabilities. On the part of society, the role of intellectuality in the management system is increasing steadily. The relationship between the State and the citizen relies on the type of contractual relations, 
based on motivational and social, rather than on political and command-and-control management techniques. The Constitution of Ukraine proclaimed the priority of civil rights and freedoms. However, in reality, civil society in Ukraine is at the stage of development and has to overcome fragmentation. Our conclusions were confirmed by a number of empirical data and comparative generalizations. The public sector of Ukraine currently needs significant support in the conditions of pandemic, consolidation and mutual strengthening of public organizations.

Education plays a major role in shaping societal attitudes. In a democratic society, where so much depends on the personal perception of each citizen, the role of education cannot be overemphasized. Citizens' acquisition of the skills of civic initiative requires civic education (Starkey, 2002). The civil society institutions are meant to balance the State power with the public interest, and economically and politically free citizens, within the framework of public associations, are able to ensure effective control in the sphere of public administration. Therefore, social control is viewed through the prism of socially useful activities of civil society.

In modern conditions, the content of social control should reflect new nature of the relationship between the State and the citizen. This means that each individual, each actor, undertaking certain commitments, in turn has the right to require others to follow these commitments for their own purposes through the actual State and public monitoring.

Thus, social control is seen as a way by which civil society institutions improve the quality of life of ordinary citizens, and the State is given the opportunity to take into account the interests of society in the processes of building a State and the creation of socio-economic base.

\section{References}

Antje, D., \& Dieter, N. (2019). "Civil society and social movements: conceptual insights and challenges in African contexts" In: Critical African Studies. Vol. 1l, No. 2, pp. 176-192. https://doi.org/10.1080/21681392.2019.1613902. Consultation date: 14/03/2021.

Brechenmacher, S., Carothers, Th., \& Youngs, R. (2020). Civil society and the coronavirus: Dynamism despite disruption. Carnegie Endowment for International Peace. Available online. In: https://carnegieendowment.org/2020/04/21/civil-society-and-coronavirusdynamism-despite-disruption-pub-81592 Consultation date: 14/03/2021. 
Brick, T. (2018). Bleeding: Diagnosis without an Analysis. Vox Ukraine. Available online. In: https://voxukraine.org/uk/krovotecha-diagnoz-bez-analizu-retsenziya-sotsiologa-narezonansnu-stattyu-dzerkala-tizhnya/ Consultation date: 14/03/2021.

CAMBRIDGE DICTIONARY (2021). Citizenship. Available online. In: https://dictionary.cambridge.org/dictionary/english/citizenship Consultation date: $14 / 03 / 2021$.

Cooper, R. (2018). What is Civil Society, its role and value in 2018. Knowledge, evidence and learning for development. Available online. In: https://assets.publishing.service.gov.uk/media/5c6c2e74e5274a72bc45240e/488_What_is_C ivil_Society.pdf Consultation date: 14/03/2021.

Etzioni, A. (1968). The Active Society: A Theory of Societal and Political Processes. Free Press. New York, NY.

Galston, W. (2004). "Political knowledge, political engagement, and civic education" In: Annual Review of Political Science. Vol. 4, pp. 217-234.

Green, S. N. (2017). Civil Society at a Crossroads: Exploring Sustainable Operating Models. Centre for Strategic and International Studies. Washington DC.

Greer, S., Wismar, M., Pastorino, G., \& Kosinska, M. (2017). "Civil society and health: Contributions and potential" In: Health Policy Series. Vol. 48. Available online. In: https://apps.who.int/iris/rest/bitstreams/1241085/retrieve Consultation date: 14/03/2021.

Howell, J. (2019). "NGOs and Civil Society: The Politics of Crafting a Civic Welfare Infrastructure in the Hu-Wen Period" In: The China Quarterly. Vol. 237, pp. 58-81. https://doi.org/10.1017/S0305741018001236. Consultation date: 14/03/2021.

HUMAN RIGHTS: NATIONWIDE RESEARCH. (2017). United Nations Development Programme in Ukraine. Available online. In: www.ua.undp.org Consultation date: $14 / 03 / 2021$.

Ivchenko, Y. (2017). "Civic patriotism as the basis of national unity (philosophical and legal aspects)" In: Entrepreneurship, economy and law. Vol. 9, pp. 223-226.

Jezard, A. (2018). Who and what is 'civil society?' World Economic Forum Agenda article. Available online. In: https://www.weforum.org/agenda/2018/04/what-is-civil-society/ Consultation date: 14/03/2021.

Klein, S., \& Lee, C. (2019). "Towards a Dynamic Theory of Civil Society: The Politics of Forward and Backward Infiltration" In: Sociological Theory. Vol. 37, No. 1, pp. 62-88.

Langseth, P. (2001). Empowering the Victims of Corruption through Social Control Mechanisms. Paper presented at IACC's Meeting. Available online. In: https://www.unodc.org/pdf/crime/gpacpublications/CICP-17_oct2.pdf Consultation date: $14 / 03 / 2021$. 
Leigh, K. (2019). Social Control and the Politics of Public Spaces. In C.E. Rabe-Hemp \& N.S. Lind (Eds.), Political Authority, Social Control and Public Policy (Public Policy and Governance, Vol. 31) (pp. 95-108). Emerald Publishing Limited. Bingli, UK. https://doi.org/10.1108/S2053-769720190000031006 Consultation date: 14/03/2021.

Lorch, J. (2017a). Analysing Civil Society in Weak States. In: Civil Society and Mirror Images of Weak States (pp. 31-70). Palgrave Macmillan. London, UK. https://doi.org/10.1057/978-1137-55462-8_2 Consultation date: 14/03/2021.

Lorch, J. (2017b). "Civil society support for military coups: Bangladesh and the Philippines" In: Journal of Civil Society, Vol. 13, pp. 1-18. https://doi.org/10.1080/17448689.2017.1312790 Consultation date: 14/03/2021.

Marañón, F., Barrientos, R. ., \& Frías, L. G. (2021). Imagen, confianza y liderazgo en voceros públicos durante la pandemia COVID-19. caso: Nuevo León, México. Journal of the Academy, (5), 7-26. https://doi.org/10.47058/joa5.2

Mchale, J. P. (2019). Mass Media, Social Control, and Political Authority in a Post-Truth Environment. In C.E. Rabe-Hemp \& N.S. Lind (Eds.), Political Authority, Social Control and Public Policy (Public Policy and Governance, Vol. 31) (pp. 259-273). Emerald Publishing Limited. Bingli, UK. https://doi.org/10.1108/S2053-769720190000031017 Consultation date: $14 / 03 / 2021$.

Primoratz, I. (2017). Patriotism. In E. N. Zalta (Ed.), The Stanford Encyclopedia of Philosophy. Available online. In: https:/plato.stanford.edu/archives/sum2017/entries/patriotism/ Consultation date: $14 / 03 / 2021$.

RAZUMKOV CENTRE. (n./d.). Available online. In: https://razumkov.org.ua/ Consultation date: 14/03/2021.

Ryabov, S. (2004). Political culture and problems of civic education in Ukraine. Tandem. Kyiv, Ukraine.

Semenets-Orlova, I., \& Kyselova, Y. (2018). "Multidimensional management contemporary: generation of social meanings for a new collective identities" In: Public Management. Vol. 4, No. 14, pp. 264-269. https://doi.org/10.31618/vadnd.vlil4.118 Consultation date: 14/03/2021.

Starkey, H. (2002). Democratic citizenship, languages, diversity and human rights. Guide for the development of Language Education Policies in Europe. From Linguistic Diversity to Plurilingual Education. Language Policy Division Directorate of School, Out-of-School and Higher Education. Council of Europe. Strasbourg, France.

STATE STATISTICS COMMITTEE OF UKRAINE. (n./d.). Available online. In: http://www.ukrstat.gov.ua/. Consultation date: 14/03/2021. 
Swain, S. (2019). "Sport, Power and Politics: Exploring Sport and Social Control within the Changing Context of Modernity" In: International Journal of the Sociology of Leisure. Vol. 2, 385-402. https://doi.org/10.1007/s41978-019-00040-4 Consultation date: 14/03/2021.

Taleb, N. (2018). Anti-malice. Nash format. Kyiv, Ukraine.

Vandyck, C. K. (2017). Concept and definition of civil society sustainability. Centre for Strategic and International Studies. Available online. In: https://www.csis.org/analysis/concept-and-definition-civil-society-sustainability Consultation date: 14/03/2021. 